\title{
Getting the Right Mix of Students: Finding a Balance between In- and Out-of-State Students
}

\author{
Dr. Michael T. Miller \\ Program in Higher Education, University of Arkansas \\ 324 Graduate Education Building, Fayetteville, AR 72701, USA \\ Tel: 479-575-3582Ｅ-mail: mtmille@uark.edu
}

Dr. Samuel M. E. Fincher

Department of Math/Physics/Engineering, Northwest Arkansas Community College

1 College Drive, Bentonville, AR 72712, USA

Tel: 479-986-4063Ｅ-mail: smefincer@gmail.com

Received: February 28, 2019

doi:10.5296/gjes.v5i1.14440
Accepted: April 8, 2019 Published: April 10, 2019

URL: https://doi.org/10.5296/gjes.v5i1.14440

\begin{abstract}
Public higher education institutions in the United States were founded on the principle of providing low-cost postsecondary educational opportunities to the state's citizenry. For a variety of reasons, including stagnant and declining funding from many state legislatures, these public institutions have actively sought the enrollment of citizens of other states, sometimes offering deep tuition discounts, and at other times relying on higher out-of-state tuition fees to help balance budgets. The motivations for these behaviors can be viewed differently based on who is looking at the institution, but there are also consequences to these behaviors. The current study was designed to explore the trends and outcomes of this out-of-state student enrollment. Study findings revealed that a number of public institutions have held consistent their out-of-state enrollment percentages over the past decade, but that there are three times as many institutions who have increased out-of-state student enrollment, and that some of these increases have been dramatic. Despite growing out-of-state student enrollment, institutions were found to have no better academic qualifications of their entering classes, and institutions that decreased their out-of-state student enrollment were actually found to have increased the diversity of their enrollment. The findings suggest a strong need for institutions and state policy makers to collaborate in defining what is expected from the
\end{abstract}


contemporary academy and the best way for institutions to be efficient and effective in meeting this defined goal.

Keywords: Student Enrollment, Higher Education Funding, Tuition, Public Education Policy, Public Higher Education Support 


\section{Introduction}

In the spring of 2017, the California legislature entered a debate about the enrollment of out-of-state students in the University of California system institutions. This debate was fueled largely by the growing number of non-Californians enrolling in publicly supported higher education, and ultimately, the legislature's involvement resulted in a cap of $18 \%$ of any individual campus' enrollment for non-Californians (Deruy, 2017; Watanabe, 2017). Such debates are not unusual, as legislators often question the enrollment of non-resident students in their state's institutions. The use of non-resident tuition, however, is often seen as a tool to garner additional revenue, and institutions have used the enrollment of non-resident students as an easy way to generate immediate cash (Redden, 2018).

Student tuition has become a mainstay in the financial stability of American higher education (Miller \& Smith, 2017), and research has supported the anecdotal perspective that institutions use out-of-state students expressly to add to their revenue (Jaquette \& Curs, 2015). The result of declining enrollments, as seen for a growing list of private institutions, is either program reduction or closure. These results are also seen at public as well as private institutions, as evidenced by Western Illinois' layoff of tenured faculty members due to declining enrollments (Zahneis, 2018).

Institutional leaders, typically with the permission from governing boards, allows for, encourages, and even subsidizes non-resident tuition driven by the thinking that such enrollment will aid cash flow into the institution. This cash flow, even at a rate that is reduced from a typical non-resident tuition rate, adds to the overall ability of an institution to access this cash on an immediate basis, subsequently allowing for physical plant improvement, better salaries, student and faculty amenities, and even program expansion. As Howard Bowen (1977) noted over 40 years ago, there is no limit to the desire for more money by higher education institutions and their leaders, and no matter how much money is generated, there are a seemingly endless number of good causes that this money can be spent on.

The problem for colleges and universities, however is more complex than simply discounting and recruiting non-resident students to add to institutional bank accounts. There has been a fundamental shift in thinking about what higher education is, does, and ultimately, who it benefits. Merrow and Hersh (2005) identified a time frame of the early-1980s when thinking shifted to a belief that higher education is a private good that benefits the individual, and as such, tuition pricing should indeed reflect the idea that an individual pays, and gains, from the experience. This perspective, for the public higher education industry, subsequently justifies to legislators and policy makers that current funding levels for higher education are most likely adequate, as individual benefit creation requires individual benefit commitment (eg, payment).

Such thinking about higher education as a private good is not universally accepted, however, as some legislators and policy makers believe that the public benefits of a higher education demand or deserve some commitment from the public. Research has demonstrated that those with a college degree not only make more money throughout their lifetimes, but that they are 
less likely to draw on un-employment, abuse alcohol and drugs, are less likely to be obese or require public support for health care, are more likely to create a desirable workforce for economic development, and that they participate at a higher rate in public service, volunteerism, philanthropy, and that they participate in the democratic process at a higher level (Baum \& Payea, 2005). So even if there is a documented private benefit to higher education, public investment in these institutions and this process does carry a benefit to society at large. Additionally, the policy practice of collecting personal property tax to subsidize higher education reflects at least a partial commitment by state legislators to support their postsecondary offerings. Subsequently, the purpose for conducting the study was to identify changes in out-of-state student enrollment and the consequences of these changes.

\section{Background of the Study}

Higher education funding has become a leading national conversation, pitting college administrators against public policy leaders in the debate about how much public funding should be allocated to campuses. The debate centers on the size of the institution's budget, with campus officials often decrying the "eroding" levels of funding. The debate is far from one-sided, however, as policy makers are often quick to note that campus budgets have explored and often include large contracts for rental space, athletics, medical facilities; all areas that are separate from the instructional aspects of operating an institution.

College students are similarly caught in the discussion of who should pay for the higher education experience. As Miller and Smith (2017) noted, students are increasingly willing to take on personal debt to 'purchase' the type of experience that they are most interested in. These experiences have been framed around amenities to the experience, such as luxury residence halls, swimming pools, maid service, etc. The implication seems to be that the college experience is one that is individual focused, rather than constructed around the ideas of community and giving back to a society.

The result is that as state's hold their funding constant to the higher education industry, institutions have found that students are willing to pay, and to use loans to make this payment. As a result of this demand, institutional leaders have found a benefit to increasing enrollment. A review of literature provides at least four distinct rationales for enrolling non-resident students in a public institution. These include revenue enhancement, optimizing efficiencies and scales of programs, cultural awareness growth or expansion, and privatization of control.

Revenue Enhancement: As institutions receive less of their direct support from state tax funding, they have come rely on tuition as an alternative revenue. This tuition can be and has been adjusted to charge non-resident students a higher rate, subsequently serving as an incentive to the institution to replace 'lost' state funds with private tuition dollars. Jaquette and Curs (2015) wrote that "state disinvestment in public higher education compels public universities to behave like private universities by focusing on attracting paying customers" ( $p$. 535). This type of tuition-dependence model has proven to provide additional funding for an institution, as well as serves as a perceived incentive for in-state students to enroll at a public institution (Miller \& Smith, 2017). 
Optimizing Efficiencies: Institutional enrollment size can be an important element in determining efficiency. Course enrollment, for example, can be more efficient and cost effective when considering marginal costs as an indicator of how well the institution is run, meaning, enrolling a certain number of students can heighten the efficiency of an institution. A course, for example, might function the same with 17 or 20 undergraduate students, and depending upon instructional costs, those additional students might be critical in cost recovery and optimizing available labor.

Cultural Awareness Growth: An area of purported value in higher education is the exposure to different cultures, races, backgrounds, and values, thus allowing for an education to include an increased understanding, and value of, other people. To provide a critical mass of students to result in this cross-cultural exchange, institutions may find that they must bring students to campus from other locations, including international settings or other nearby states. Lee and Ngo (2017) noted both the growing multiculturalism throughout the United States, but also the importance of cultural exposure to aid in the preparation of those working in education, healthcare, and other human services.

Privatization of Control: As public funding for higher education has remained relatively stable, without increases, there have been challenges to the right of the state assembly to appoint or control institutional governance. This is most often a situation where a legislature will provide a fraction of less than half of an institutions operating budget, but will have complete control over who will be allowed to govern the institution through a board of trustees or similar oversight body. By recruiting and enrolling non-resident students, institutions strengthen their case for independence from state control, arguing that their reach, and resulting financial independence, are so extreme that they should be exempt from state politics and political functioning.

\section{Research Methods}

To identify a sample for the study, all US institutional members of the Association of Public and Land Grant Universities was consulted. This membership represents typically the flagship or primary college or university in each state, and their membership list includes 195 distinct institutions. From this listing of institutions, four specialty institutions were removed from consideration (such as a medical school and community college), leaving a potential sample of 191 institutions. For the exploratory nature of the study, 50 institutions were then randomly selected from the membership list.

Data were identified from the 2007-2008 and 2017-2018 Common Data Set (CDS) reports available online from each institution. These archived reports were typically identified in offices of institutional research, effectiveness, or planning. As a cautionary note, the 2007-2008 CDS reported 'total undergraduate enrollment' and the 2017-2018 CDS differentiated degree-seeking and non-degree seeking enrollment, both combined and separate. For the purpose of this study, combined data for degree and non-degree seeking students in 2017-2018 was used in analysis. Additionally, out-of-state student enrollment data excluded international student enrollment. 
From the initial sample of 50 institutions, 20 were found to not have listed or provide to the public their Common Data Set report. Of these 20, 6 provided no reference to the Common Data Set report, and 14 reported either the 2007-2008 or the 2017-2018 report, but not both. As a result, these 20 institutions were removed from the sample listing, and another 20 institutions were selected. Following that analysis, another 8 institutions were found to have either incomplete, inconsistent, or non-reported data sets, and 8 additional institutions were then selected. The same process was then used to replace 4 institutions from the additional 8 which did not provide complete or historical data.

One institution was removed from analysis due to the nature of their data reporting, when the institution initially reported CDS data for a system and later changed to individual campuses.

In addition to enrollment data, the $25^{\text {th }}$ percentile of ACT composite scores were identified for both the 2007-2008 and 2017-2018 academic years, along with number of diverse students in the freshman cohort, and the percentage of the freshman cohort with a 3.75 grade point average or higher. The numbers of total students were also identified for the institutions in the sample, noting both the out-of-state student enrollment and the in-state student enrollment to allow for a comparison of total enrollment growth.

\section{Findings}

For the institutions selected for the study, they enrolled, on average, $19 \%$ of their student body from out-of-state students in 2007, and that figure grew to $23 \%$ by 2017 . Of the 50 institutions, as shown in Appendix 1, 8 enrolled the same percentage of out-of-state students between 2007 and 2017, and 8 actually decreased their out-of-state enrollment. This means that 34 institutions increased their out-of-state enrollment, some by a percentage point, and some doubling (Ball State, Arkansas, UC-San Diego), tripling (Oregon State, Alabama), or even quadrupling their enrollment (Memphis).

For the institutions who reported a decrease in out-of-state student enrollment, the University of Idaho experienced the biggest decrease with $17 \%$ fewer out-of-state students, and on average, the average decrease for the 8 institutions was $7.25 \%$. There were two institutions, Idaho and Florida A \& M that both reported decreases over 10\%. For 34 institutions reporting a growth in student out-of-state enrollment, 8 reported growth over $10 \%$, and overall, the growth was $7.5 \%$. The largest growth was reported at the University of Alabama which reported a $37 \%$ growth in out-of-state enrollment.

The increases or decreases in out-of-state enrollment may or may not be intentional on the part of the institution, but there could be consequences to these enrollment shifts. One argument noted at the University of Virginia was that by increasing non-resident students, perhaps a change in governing board structure should be enacted to restrict the state's ability to manage the institution. Aside from those policy types of questions, the current study attempted to look at the diversity of enrollment and the academic qualifications of students.

In terms of the examination related to diverse student enrollment, the overall number of diverse student enrollment for the overall student population was extracted from each institution's Common Data Set reporting for 2007 and 2017. These data were then used to 
compare diverse student enrollment growth for institutions based on the percentage of increased out-of-state student enrollment. As shown in Table 1, as out-of-state student enrollment decreased, the percentage of the enrollment from diverse (non-international) backgrounds increased significantly.

Table 1. Independent samples test results for diversity change

\begin{tabular}{|c|c|c|c|c|c|c|}
\hline F & Sig. & t & df & Sig (2-taled) & Mean Diff & Std. Error Diff \\
\hline 2.979 & .099 & 2.210 & 21 & .038 & 1.42 & 642 \\
\hline
\end{tabular}

An additional independent sample t-test indicated that despite the change in out-of-state student enrollment, there were no significant changes to the academic credentials of student population (see Table 2).

Table 2. Independent samples test results for academic profile change

\begin{tabular}{|c|c|c|c|c|c|c|}
\hline $\mathrm{F}$ & Sig. & $\mathrm{t}$ & $\mathrm{df}$ & Sig (2-taled) & Mean Diff & Std. Error Diff \\
\hline .946 & .344 & -2.43 & 17 & .026 & -1.630 & .67076 \\
\hline
\end{tabular}

\section{Discussion and Conclusions}

Public higher education institutions clearly have significant challenges. They are charged with educating the sons and daughters of their states, but are allocated limited resources to accomplish that lofty goal. A logical response strategy would have been to assign different public institutions clearly prescribed roles and responsibilities, but instead, an evolution of capitalistic-based competition among public agencies has been allowed to arise. The logic of a capitalistic-based competition would mean that public agencies receive public monies to duplicate efforts, and ultimately, the institution that can do it the best will force the others out of business. The difficulty with that thinking is that it not only could take an extraordinarily long time to accomplish, but that considerable public monies would be spent on program duplication and institutions can artificially inflate their numbers and prolong program survival through the enrollment of out-of-state students.

A dominant reason that appears to be present for the increase in out-of-state student enrollment is the desire to increase revenue for the institution. Such a practice can provide much needed funding to help an institution grow programs, maintain its physical infrastructure, and keep funding available to provide benefits to employees. This public practice, however, runs counter to some of the rationale for funding public education, and most likely provides an alternative incentive for the provision of public higher education. Instead of helping a state by bringing new potential employees to the area or region and importing possible future labor, the practice creates problems from the larger perspective of 
society at-large. Institutional leaders will be quick to argue that their practices increase the economic benefit to a region, infusing potentially millions to a community or state, but this is an entirely economic perspective that might not consider the overall welfare of state's decision to offer public higher education. What must be admitted by the public policy makers is simply that enrolling out-of-state students has benefits, and disadvantages, and the practice must be considered from a perspective of more than the immediate financial gain of a university and its host city.

The findings in this study lead to the conclusion that by enrolling more out-of-state students does not help diversify institutional enrollment, suggesting that by not relying on these non-resident students, institutions are forced to recruit their own state's populations more aggressively and the result is a more diverse in-state student population. Additionally, findings lead to the conclusion that simply by pursuing and enrolling out-of-state students does not automatically lead to a stronger academic class being enrolled.

The future of higher education is not and will not be determined by higher education leaders alone, nor the students and parents and employers who make use of the academy. Instead, state policy leaders and legislators must work to do more than pass one-time, stop-gap legislation to fix immediate real or perceived problems, but rather, must think strategically about what society needs from higher education. Critical discussions that dissect the value of work, an educated citizenry, the need for socially integrated, well-balanced individuals who pursue a high quality of life must play roles in these discussion, and policy leaders must increasingly work to place the welfare of the state above the self-interests of college leaders who seem content to pursue Bowen's laws of higher education finance.

\section{References}

Baum, S., \& Payea, K. (2005). Education pays. New York, NY: The College Board.

Jaquette, O., \& Curs, B. R. (2015). Creating the out-of-state university: Do public universities increase nonresident freshman enrollment in response to declining state appropriations? Research in Higher Education, 56, 535-565. https://doi.org/10.1007/s11162-015-9362-2

Lee, K. M., \& Ngo, M. A. (2017). Effect of graduate students' internationalization experiences on cultural competence. Journal of Higher Education Management, 32(1), 66-84.

Merrow, J., \& Hersh, R. H. (2005). Declining by degrees. New York, NY: Griffin.

Miller, M. T., \& Smith, E. A. (2017). An analysis of the Hanson-Liethen sliding scale cost recovery model for college tuition: A case study. Journal of Educational Studies, 3(2), 26-38. https://doi.org/10.5296/gjes.v3i2.11409

Miller, M. T., \& Smith. E. A. (2016). Brand consciousness and college debt: Does student attendance location make a difference? Journal of Educational Studies, 3(3), 97-103.

Deruy, E. (2017, May 12). UC set to limit number of out-of-state students. San Jose Mercury News. Retrieved from http://www.mercurynews.com/2017/05/12/uc-set-to-limit-number-of-out-of-state-students/ 


\section{Macrothink}

Global Journal of Educational Studies

ISSN 2377-3936

2019, Vol. 5, No. 1

Watanabe, T. (2017, May 18). UC regents approve first limit on out-of-state and international student enrollment. Los Angeles Times. Retrieved from http://www.latimes.com/local/education/la-essential-education-updates-souther-uc-regents-ap prove-first-ever-limit-on-1495123220-htmlstory.html

Redden, E. (2018, June 25). Eastern Michigan offers resident tuition rate to international undergraduates. Insidehighered.com. Retrieved from http://www.insidehighered.com/admissions/article/2018/06/25/eastern-michigan-offers-reside nt-tuition-rate-international

Zahneis, M. (2018, June 28). Western Illinois will lay off 24 faculty members, including 7 with tenure. Chronicle of Higher Education. Retrieved from http://www.chronicle.com/article/Western-Illinois-Will-Lay-Off/243790

Appendix 1.

Out-of-State Student Enrollment at Select Institutions

\begin{tabular}{|l|c|c|c|c|}
\hline & Fall 2007 & \% of all & Fall 2017 & $\%$ of all \\
\hline Arkansas State University & 1,032 & 11 & 9,839 & 11 \\
\hline Auburn University & 6,142 & 31 & 8,387 & 35 \\
\hline Ball State University & 1,1314 & 08 & 2,551 & 15 \\
\hline Clemson University & 4,281 & 30 & 5,821 & 34 \\
\hline Colorado State University & 3,685 & 17 & 6,216 & 24 \\
\hline East Carolina University & 4,418 & 17 & 2,326 & 10 \\
\hline Florida A\&M University & 2,517 & 27 & 981 & 13 \\
\hline Florida International University & 941 & 03 & 1,903 & 04 \\
\hline George Mason University & 2.045 & 11 & 2,499 & 10 \\
\hline Georgia Institute of Technology & 3,643 & 29 & 4,994 & 33 \\
\hline Indiana University & 10,752 & 34 & 11,366 & 34 \\
\hline Iowa State University & 4,410 & 21 & 10,642 & 35 \\
\hline Kansas State University & 2,596 & 14 & 3,327 & 18 \\
\hline Miami University (OH) & 4,366 & 30 & 6,173 & 36 \\
\hline Montana State University & 3,277 & 31 & 5,489 & 38 \\
\hline Montclair State University & 260 & 02 & 500 & 03 \\
\hline Mississippi State University & 2,245 & 17 & 5,493 & 30 \\
\hline North Carolina State University & 1,690 & 07 & 2,415 & 10 \\
\hline Ohio State University & 4,313 & 11 & 8,729 & 19 \\
\hline Oregon State University & 1,785 & 11 & 8,268 & 32 \\
\hline Purdue University & 8,420 & 27 & 11,162 & 36 \\
\hline SUNY, University at Albany & 637 & 05 & 675 & 05 \\
\hline Temple University & 5,611 & 22 & 6,205 & 21 \\
\hline
\end{tabular}




\section{Macrothink}

Global Journal of Educational Studies

ISSN 2377-3936

2019, Vol. 5, No. 1

\begin{tabular}{|l|c|c|c|c|}
\hline Texas A\&M University & 1,494 & 04 & 2,123 & 04 \\
\hline University of Alabama & 4,848 & 23 & 19,983 & 60 \\
\hline University of Alabama-B'ham & 1,079 & 07 & 1,444 & 11 \\
\hline University of Arizona & 9,883 & 34 & 10,536 & 30 \\
\hline University of Arkansas & 3,587 & 24 & 10,369 & 45 \\
\hline University of California, San Diego & 661 & 03 & 4,848 & 06 \\
\hline University of Central Florida & 2,066 & 05 & 3,418 & 06 \\
\hline University of Delaware & 9,497 & 62 & 11,249 & 62 \\
\hline University of Florida & 1,407 & 04 & 2,114 & 06 \\
\hline University of Georgia & 2,787 & 11 & 3,173 & 11 \\
\hline University of Houston & 551 & 02 & 372 & 01 \\
\hline University of Idaho & 3,426 & 38 & 2,075 & 21 \\
\hline University of Illinois & 2,162 & 07 & 3,395 & 10 \\
\hline University of Kansas & 4,790 & 23 & 5,414 & 28 \\
\hline University of Louisville & 1,795 & 12 & 2,643 & 17 \\
\hline University of Memphis & 474 & 03 & 2,087 & 12 \\
\hline University of Nebraska & 3,069 & 17 & 4,819 & 23 \\
\hline University of New Hampshire & 5,188 & 43 & 6,872 & 53 \\
\hline UNC-Charlotte & 1,598 & 09 & 956 & 04 \\
\hline University of North Texas & 817 & 03 & 942 & 03 \\
\hline University of Northern Colorado & 916 & 09 & 1,596 & 16 \\
\hline University of Pittsburgh & 2,925 & 17 & 5,411 & 28 \\
\hline University of Texas at Dallas & 369 & 04 & 733 & 04 \\
\hline University of Toledo & 1,652 & 10 & 3,238 & 20 \\
\hline Washington State University & 2,028 & 10 & 3,286 & 13 \\
\hline University of Wisconsin-Madison & 9,280 & 32 & 10,946 & 34 \\
\hline University of Wyoming & 2,657 & 28 & 3,321 & 33 \\
\hline AVERAGE & $19 \%$ & & $23 \%$ & \\
\hline STD DEV & 9.5078 & & & \\
\hline & & & & \\
\hline
\end{tabular}

\section{Copyright Disclaimer}

Copyright for this article is retained by the author(s), with first publication rights granted to the journal.

This is an open-access article distributed under the terms and conditions of the Creative Commons Attribution license (http://creativecommons.org/licenses/by/3.0/). 